\title{
The Essential Need to Clearly Define Addiction Criticism in Literature Studies
}

\section{Jason Walter}

Department of Humanities and Social Sciences, East Georgia State College, 1008 Merry St. Augusta, GA 30904, United States.

Article Details
Article Type: Mini Review
Received date: $27^{\text {th }}$ April, 2021
Accepted date: $03^{\text {rd }}$ May, 2021
Published date: $24^{\text {th }}$ May, 2021

"Corresponding Author: Jason Walter, Department of Humanities and Social Sciences, East Georgia State College, 1008 Merry St. Augusta, GA 30904, United States. E-mail: jwalter@ega.edu

Citation: Walter, J. (2021). The Essential Need to Clearly Define Addiction Criticism in Literature Studies. J Ment Health Soc Behav 3(1):141. https://doi.org/10.33790/jmhsb1100141

Copyright: $\left({ }^{2} 2021\right.$, This is an open-access article distributed under the terms of the Creative Commons Attribution License 4.0, which permits unrestricted use, distribution, and reproduction in any medium, provided the original author and source are credited.

\section{Introduction}

Upon reading The Second Edition of The Bedford Glossary of Critical Literary Terms, I was surprised to find that many traditionally uncharted fields of exploration in literature are being given critical attention; postcolonial studies, race (and literary studies), queer theory, feminist criticism, cultural criticism, ecocriticism, disability criticism, and gender criticism have emerged and evolved tremendously in recent years [1]. We are living in Prospero's "Brave New World" in which traditionally marginalized voices are being involved in the larger intellectual discussion. We're addressing that making fun of the mute or mentally handicapped in literature is a microcosm of society's larger prevailing attitudes towards the disabled. Likewise, we're accessing how personifying Nature in literature can further the prevailing attitudes that Nature is merely a subservient means for men to use to preserve humans' reflective image. Literature criticism has made great strides, but we still have much more room to grow because an essential question remains unaddressed: Why isn't addiction criticism a clearly defined field of study in literature?

According to David Sheff [2] in his book Clean published in 2013, arguably all of the United States' problems with violence, murder, theft, suicide, and mental illness have some overlapping congruency with Americans' propensity towards addiction (3-11). Our unbridled capitalist system allows Americans to achieve as many resources as they like, but unbridled capitalism has also created an addicted culture. Between alcoholism, drug addiction, sex addiction, gambling addiction, pornography addiction, social media addiction, video game addiction, junk food addiction, and soda addiction; Americans who aren't addicted in at least one way are a minority in number. It's not surprising that programs such as Alcoholic Anonymous, Narcotics Anonymous, Sex Addicts Anonymous, and Gamblers Anonymous were born and bred in the United States. Addiction is, of course, an extremely complex problem that has no easy solution, but as academics, we must begin extensively examining how addictive substances and behaviors are being addressed in literature and in the various media that are analyzed in cultural studies classes. Teachers are in the unique position to present their students with the reality surrounding addiction, but far more often than not, teachers are neglecting to do so altogether, or teachers are romanticizing addiction, which is even worse than not addressing addiction whatsoever, in my opinion.

A large part of why I think alcohol studies is not as clearly defined as the other criticisms that have emerged in the last fifty years is because a romantic attitude towards addiction is the prevailing viewpoint on addiction in America. From an extremely age, an American child watches cartoons, reads comic strips, watches movies, reads books, and hears stories in which the positive social effects of addictive substances are praised and highlighted, which also means that the negative physical and mental effects are deemphasized by default. American culture is riddled with the message that using addictive substances is fun, exciting, pleasurable, and desirable. Soda machines, beer commercials during televised football games, fast food restaurants, prescription pills, binge tweeting, and online poker are all as American as apple pie, which is also addictive these days because the dessert is laced with copious amounts of sugar or sugar substitute by the companies who profit from their consumers' addiction to their product. The obesity epidemic is an immensely palpable and hard-to-deny sign that Americans need to be saved from themselves. However, there's hardly anything anyone can do to stop a junkie from getting their fix in our present climate besides presenting the addict with the facts. Academics are paid to instill critical thinking skills in young minds, so college professors are the ones who definitely need to step up to the plate and begin analyzing how addiction is being presented in literature and in media.

College is a playground in which students are finally able to extensively experiment in the addictive substances that they previously didn't have access to, weren't old enough to use, or were punished for using. Many students have already engaged with some form or another of an addictive substance by the time they've gotten to college, but once their parents drop their former child off at the dorm room, the college student is finally able to begin their career as a full-time partyer. The party takes place both off campus and in the classroom because the students' Humanities professor may very well be yet another individual in the student's college experience who enables the student's party lifestyle. For example, the literature professor might gloss over Edgar Allen Poe's addiction completely in order to have the time to focus on Poe's contributions to detective fiction, Gothic literature, and American horror. Instead of using Poe's death as a teachable moment to present their hungover students with the possible reality and future of their party lifestyle, the teacher chooses to essentially reinforce the prevailing lackadaisical attitude towards addiction by default. Honestly, I feel that all of Poe's frequently anthologized poems and short stories are metaphors for the addictive mindset on some level even when the protagonist isn't an overt addict as is the case with the murderous speaker of "The Tell-Tale Heart" [3]. To me, when I read an Edgar Allen Poe poem or short story, the subtext is that Poe is 
desperately looking for a solution to his alcoholic disease in an America that has literally no solution for the alcoholic problem other than hospitalization, institutionalization, or arrest. Even worse than neglecting to give a critical viewpoint on addiction and far more common than not, in my opinion, the college English professor romanticizes the alcoholic experience. For example, the college professor might focus on the wit and humor in Emily Dickinson's poem "I taste a liquor never brewed" [4] or focus on the arguably transcendent experience achieved at the end of a long night of drinking and smoking marijuana in Raymond Carver's "Cathedral" [5]. The English professor might even have his students meet up in a bar so that they can have a discussion about Carver's work over a drink, without ever acknowledging the highly ironic fact that Raymond Carver recovered from his alcoholic disease towards the end of his adult life as a result of his membership to Alcoholics Anonymous. Addiction criticism might not exist because college English professors reflect the larger prevailing attitude towards addiction, which is either to romanticize addiction or to not address the reality of addiction whatsoever.

Whenever addiction is mentioned in literature or in the media that is analyzed in cultural studies classes, it's vitally important that professors acknowledge the reality of the addict in order to stop future deaths. Addiction is a disease that some individuals are more genetically disposed to than others. Likewise, addiction is a disease in which the sick individual is delusional about the inherent nature of their sickness. A person who contracts skin cancer from overly sun tanning would probably not go back to sun tanning after successfully working to send their disease into remission. The addict, however, often relapses after they have sent their addiction into remission. Even though the addict's life greatly improves when the individual stops using their drug of choice, the addict's disease makes the individual think that because they have recovered, they are cured of their illness. As a result, they are deluded in thinking that they can have just one beer, just one hit of dope, just a single one-night-stand, or just one donut. Within minutes, the addict's symptoms are even worse than when he first became sober or stopped using. Addiction is a progressive disease even when the disease is in remission. Furthermore, once an addict crosses the line into addiction, the fun parties and romantic nights of revelry are over because the addict's thoughts and behaviors are entirely enslaved to the substance that was once an innocuous social lubricant. Instead of glamour and allure, the addict's life becomes riddled with arguments, violence, depression, poverty, thoughts of suicide, thoughts of homicide, and an altogether infantile state of being even though the individual is never much an adult who should be able to take care of themselves and their families. Nevertheless, the addicted individual refuses to seek counsel or get help for his illness because the delusional addict tells themselves that their problem isn't nearly as bad as others make it out to be. Likewise, the American addict probably downplays the severity of their disease because the prevailing attitudes of the general populace and greater institutions differ greatly from the reality of addiction.

The discussion of the adverse effects of addiction needs to begin in the classroom because choosing to romanticize addiction or to neglect an analysis of addiction altogether results in the teacher performing a great disservice to the young, burgeoning minds in their classroom who may have never been told that they very likely might have a disease that they are genetically disposed to, a disease that tricks the addict's mind from acknowledging the fact that they have a disease. If the college professor doesn't present the student with the harsh truth concerning addiction, then the student might die before anyone feels the need to inform the student about the facts. Likewise, the truth concerning addiction is largely ignored by the general public in the United States, so the student might not even know where to even look for the correct information regarding alcoholism even if they were curious or in dire need. The internet is saturated with skewed information, romanization, and half-truths concerning alcohol. Likewise, one's peers in college are mirrors of the student's delusional addicted mindset; the group think that occurs among cliques in colleges only places the student further along the path towards full-blown addiction. Academics need to step up to the plate and begin addressing, discussing, and espousing their students' misconceptions concerning alcoholism that are mirrored in Western literature and American media.

Competing interests: There is no conflict of interest.

\section{References}

1. Murfin, Ross and Ray, Supryia, M. (2003). The Bedford Glossary of Critical and Literary Terms.

2. Sheff, David. (2013). Clean: Overcoming Addiction and Ending America's Greatest Tragedy. Houghton Mifflin Harcourt: Boston.

3. Poe, Edgar Allen. (2012). "The Tell-Tale Heart." Backpack Literature. Gioia, Dana and Kennedy, X.J., eds.

4. Dickinson, Emily. (2012). "I taste a liquor never brewed." Backpack Literature. Gioia, Dana and Kennedy, X.J.,

5. Carver, Raymond. (2012). "Cathedral." Backpack Literature. Gioia, Dana and Kennedy, X.J., eds. 